\title{
PERAN ORGANISASI DALAM PEMBENTUKAN KARAKTER MAHASISWA
}

Aprina Jovanka Sirait, Chontina Siahaan

Universitas Kristen Indonesia (UKI) Jakarta, Indonesia

Email: aprinajvnka14@gmail.com, chontinasiahaan58@gmail.com

\section{Diterima \\ 22 Juni 2020 \\ Direvisi \\ 6 Juli 2020 \\ Disetujui \\ 10 Juli 2020}

INFO ARTIKEL

Kata Kunci:

Perguruan tinggi, Peran Organisasi, Ormawa, Karakter Mahasiswa

\begin{abstract}
ABSTRAK
Dalam sebuah perguruan tinggi peran terpentingnya adalah mengembangkan sumber daya manusia melalui penyelenggaraan Tridharma Pendidikan Tinggi, yaitu pelaksanaan pendidikan dan pengajaran, penelitian dan pengabdian kepada masyarakat. Namun, dibalik peran terpentingnya tadi, perguruan tinggi juga memiliki tanggung jawab untuk memberikan ilmu kepada para mahasiswa sebagai salah satu pelatihan sebelum mereka terjun ke dalam dunia kerja. Dengan melalui aktifitas organisasi kemahasiswaan (ormawa) yang ada di kampus seperti Badan Eksekutif Mahasiswa (BEM), Himpunan Mahasiswa Jurusan, dan Unit Kegiatan Mahasiswa (UKM). Penelitian ini bertujuan untuk melihat seberapa besar pengaruh organisasi mahasiswa (ormawa) terhadap pembentukan karkater para mahasiswa di suatu perguruan tinggi. Dan untuk perihal metode yang digunakan penulis yaitu studi kepustakaan dimana sumbernya diambil dari berbagai tempat mulai dari artikel, berita serta dokumen yang berkaitan dengan kegiatan organisasi kemahasiswaan. Berikutnya data tersebut kemudian dianalisis dengan metode deskriptif yaitu metode yang berusaha untuk mengungkapkan hasil dan pernyataanpernyataan yang sumbernya sudah didapatkan sebelumnya. Hasil dari penelitian ini menunjukkan bahwa organisasi mahasiswa memiliki peran yang cukup besar dalam membentuk nilai-nilai karakter melalui aktifitas mahasiswa yang disediakan dalam perguruan tinggi. Dikarenakan peran ormawa yang ada di kampus terhadap pembentukan karakter mahasiswa maka nantinya mahasiswa dapat memiliki pengetahuan dan pengalaman dalam berorganisasi, serta pembentukan karakter yang nantinya bisa menjadi ciri khas dari mahasiswa tersebut.
\end{abstract}

ABSTRACT
In a university, the most important role is to develop human resources
through the implementation of the Tridharma of Higher Education,
namely the implementation of education and teaching, research and
community service. However, behind its most important role, universities
also have a responsibility to provide knowledge to students as one of the
trainings before they enter the world of work. By going through the
activities of student organizations (ormawa) on campus such as the
Student Executive Board (BEM), Department Student Associations, and
Student Activity Units (UKM). This study aims to see how much influence
student organizations (ormawa) have on the character formation of
students in a university. And regarding the method used by the author,
namely library research where the sources are taken from various places
ranging from articles, news and documents related to student
organization activities. Next, the data is then analyzed using a descriptive


method, which is a method that seeks to reveal the results and statements whose sources have been obtained previously. The results of this study indicate that student organizations have a significant role in shaping Keywords: $\quad$ character values through student activities provided in universities. Due College, to the role of ormawa on campus in the formation of student character, Organizational later students can have knowledge and experience in organizing, as well Role, Ormawa, as character building which can later become the hallmark of these Student Character students..

\section{Pendahuluan}

Era modern ini dan zaman yang semakin canggih menuntut kita untuk berfikir luas dan kreatif dalam menyikapi pergaulan khususnya bagi mahasiswa (Almaidah, 2018). Banyak fenomena yang terjadi pada kegiatan siswa diluar yang lebih banyak ketimbang fokus belajar di sekolah seperti halnya geng motor, komunitas yang tidak tentu arah visi misinya bagi siswa itu sendiri ataupun tawuran sekalipun bahkan baru baru ini perilaku dan etika siswa ada saja yang berani melakukan tidakan yang tidak dibenarkan oleh aturan sekolah ataupun hukum, baik mengenai tindakan melawan atau dengan tindakan kasar lainnya kepada guru.

Hal tersebut menjadi sorotan masyarakat luas khususnya bagi publik di lingkungan pendidikan. Berdasarkan hal tersebut ini tentunya menjadi bahan untuk kita pikirkan bagaimana mencari solusi terbaik dalam menyikapinya sehingga siswa mampu menjaga prilakunya dengan baik dan proses pendidikan yang dilaksanakan memberikan nilai positif untuk masyarakat luas. Siswa yang mudah terpengaruh lingkungan luar yang bisa berakibat pula terhadap kegiatan disekolah karena kurangnya motivasi siswa terhadap organisasi.

Dan hal di atas tersebut masih dalam ranah sekolah, belum masuk ke dalam perguruan tinggi. Lalu bagaiamana dengan Mahasiswa yang adalah cendekiawan yang mempunyai tanggung jawab yang harus senantiasa dilaksanakan. Disinilah diperlukan suatu wadah untuk melatih tanngung jawab sebagai mahasiswa. Organisasi lah wadahnya, tugas utama dalam berorganisasi yaitu mencapai tujuan yang sudah dibuatnya terlebih dahulu (Hemafitria et al., 2014). Organisasi ini juga bisa dikatakan suatu wadah dari sekelompok orang yang ada di dalamnya dengan memiliki harapan untuk mencapai tujuan bersama yang ada di organisasi tersebut. Dengan begitu,sudah bisa dikatakan bahwa organisasi yang ada di perguruan tinggi itu merupakan hal yang penting dalam rangka pengembangan karakter diri para mahasiswa. Teori yang di atas merujuk kepada fungsi organisasi nantinya yaitu untuk mempersiapkan calon calon yang akan terjun langsung ke dalam masyarakat yang mengharuskan kita berani mengemukakan pendapat, memiliki rasa tanggung jawab, berani mengambil keputusan dan juga mempraktikan keterampilan yang sudah ditemukan dalam organisasi.

Selain itu juga, mahasiswa yang adalah agent of change (agen perubahan) para calon pemimpin masa depan bangsa yang diharapkan dapat membawa perubahan ke ranah yang lebih baik bagi bangsa ini. Dan untuk meralisasikan harapan tersebut maka dibutuhkan lah organisasi mahasiswa dalam menyusun strategi untuk membantu masyarakat. Di dalam sebuah jurnal (AsySyarif \& Sasongko, 2021) dijelaskan bahwa terdapat kelebihan dan potensi yang dimiliki dalam sebuah organisasi, yaitu:

1 Ormawa menjadi satu organisasi yang bisa diandalkan dalam suatu perguruan tinggi

2 Sudah memiliki keabsahan yang resmi secara hukum dalam melakukan suatu kegiatan

3 Ormawa juga sudah berada dibawah naungan lembaga yang membuat 
organisasi tersebut bisa lebih berkomitmen untuk menjalankan tugas dan tujuannya.

Menurut (Basri \& Dwiningrum, 2020) organisasi kemahasiswaan atau yang bisa disingkat menjadi "ormawa" yang ada dalam perguruan tinggi memiliki fungsi sebagai sarana mahasiswa untuk menyalurkan dan menampung tiap pendapat maupun aspirasi tiap mahasiswa. Disebutkan juga bahwa pengembangan diri mahasiswa yang adalah insan akademis itu melalui pelatihan keterampilan yang ada di organisasi. Hal tersebut akan sesuai dengan pengembangan kader-kader bangsa yang memiliki potensi untuk melanjutkan dan mengembangkan ilmu pengetahuan dan teknologi yang pastinya dilandasi oleh norma-norma yang ada.

Dari data di atas ditemukan fakta bahwa ternyata masih banyak anggapan negative perihal organisasi tersebut. Hal tersebut disebabkan oleh adanya pemahaman mahasiswa yang salah dalam memandang.

\section{Metode Penelitian}

Dalam penelitian ini, penulis memakai studi kepustakaan (Danandjaja, 2014) dimana penulis berusaha untuk melihat dan membaca penelitian terlebih dahulu yang sudah dilakukan dalam beberapa jurnal kemudian penuli mencoba merangkum hasilnya dan metode yang digunakan adalah Penelitian Deskriptif, metode yang bertujuan untuk membuat deskripsi secara sistematis, faktual, serta akurat pada fakta dan sifat populasi atau daerah tertentu dan peneliti juga berusaha mengungkap pernyataan-pernyataan yang berasal dari sumber sudah didapat. Setelahnya baru penulis mendapat hasilnya dari beberapa bacaan kemudian di paraphrase terlebih dahulu hingga akhirnya menjadi suatu jurnal ini.

\section{Hasil dan Pembahasan}

Menurut (Sofyan, 2013) menjelaskan bahwa tiap mahasiswa yang adalah peserta didik itu mempunyai kemampuan yang heterogen. Dengan arti lain, kami pribadi yang satu dengan yang lain pasti memiliki latar belakang yang berbeda. Maka dari itu, diperlukan pembinaan yang secara terusmenerus, juga adanya pengembangan dalam akademik, fasilitas teknologi informasi yang mumpuni sehingga berbagai hal tesebut dapat memicu pengembangan minat dan bakat para mahasiswa. (Omeri, 2015) menekankan bahwa Pendidikan karakter merupakan system yang meliputi aspek pengetahuan yang disertai kedasaran dan tingkah laku melalukan nilai karakter. Pengembangan karakter bisa dilakukan dengan mengembangkan karakter individu dalam lingkungan sosial dan budaya berdasarkan potensi peserta diidk yang menunjang Kesehatan mental siswa.

Dewasa ini, pengaruh globalisasi dangat dirasakan bagi seluruh lapisan masyarakat di dunia, termasuk di Indonesia ini. Ada pengaruh positif dan negatifnya, dari sisi positifnya ialah terjadi kemajuan daam hal teknologi komunikasi yang membuat masyarakat mudah menjadi informasi. Sedangkan dampak negatifnya adalah terjadi kelunturan karakter dan budaya bangsa ini. Seperti yang sudah kita ketahui dampak negatif juga yang berasal dari globalisasi itu adalah ketimpangan budaya (culture lag), kegoncangan budaya (culture shock).

Berdasarkan fakta yang ada di atas tersebut maka peneliti akan membahas apa saja manfaat organisasi, peran mereka dalam pembentukan karakter mahasiswa dan juga membahas apa saja kendala dalam mengikuti organisasi dan cara mengupayakannya.

A. Manfaat Berorganisasi

Dalam hal berorganisasi dapat dikatakan banyak sekali benefit yang akan didapatkan nantinya. Dengan berorganisasi itu sendiri, mahasiswa dapat melatih jiwa kepemimpinan nya untuk bisa mengatur diri sendiri, orang lain maupun organisasi itu. Fungsi-fungsi tidak akan terlepas apabila kita sudah memasuki suatu organisasi mahasiswa.

Setiap pribadi mahasiswa memiliki sifat dan pemikirannya masing-masing. Disinilah mahasiswa dapat sama-sama belajar bagaimana cara untuk menghadapi/merespon orang lain dengan bijak. Bahkan dalam berorganisasi itu juga mendapatkan pengalaman untuk 
berbicara/berhadapan dengan orang penting dalam perguruan tinggi (contoh: berbicara dengan dekan, maupun rektorat.

Dalam satu jurnal (岡戸順一 et al., 2003) dijelaskan bahwa organisasi itu merupakan media yang dapat digunakan untuk membentuk kematangan mahasiswa dalam bermasyarakat. Adapun manfaat berorganisasi yaitu sebagai berikut:

1 Menambah relasi

2 Belajar memahami orang lain

3 Belajar mengatur waktu dengan baik

4 Memiliki rasa tanggung jawab yang tinggi

5 Memiliki kreatifitas

6 Memperluas wawasan

7 Melatih diri sebelum terjun ke lapangan

8 Meningkatkan kemampuan berkomunikasi

9 Mengembangkan karakter.

\section{B. Kendala \& Cara Mengupayakan}

Berdasarkan data dalam suatu penelitian ditemukan beberapa hambatan yang terjadi saat ingin bergabung dalam sebuah organisasi (Kusuma, 2018). Hambatan tersebut terbagi dari 2 sisi yaitu, sisi internal dan sisi eksternal. Dari sisi internal tersebut adalah kurangnya minat mahasiswa untuk mengikuti suatu organisasi, memiliki pendapat jika berorganisasi hanya membuang waktu. Sedangkan dari sisi eksternalnya ialah kurang mendapat izin untuk masuk dalam suatu organisasi, perlengkapan yang masih harus dibiayai dengan uang pribadi, dan latar belakang mahasiswa. Hambatanhambatan tersebut menjadi masalah besar bagi mahasiswa-mahasiswi yang ada di perrguruan tinggi. Lalu bagaimana cara mengatasi hamabatan-hambatan yang ada tersebut?

Jika membahas apakah ada upaya yang bisa dilakukan saat terjadi penghambatan ? Tentu ada, dalam permasalahan kali ini pun terdapat solusinya. Berikut beberapa upaya yang dapat dilakukan:

1 Melakukan pengkaderan yang kuat

Pengkaderan disini bermaksud untuk membentuk suatu mindset mahasiswa yang ingin bergabung ke dalam organisasi terlebih dahulu dengan cara membuat agenda/program kerja organisasi yang menarik, memberitahu tentang apa saja manfaat dari berorganisasi, dan juga mahasiswa akan lebih tertarik masuk jika pendapatnya diterima dengan baik

2 Melakukan penggalangan dana

Sudah dijelaskan bahwa salah satu hambatan adalah kurangnya dana yang dimiliki suatu organisasi, maka dari itu penggalanan dana lah yang harus dilakukan oleh anggota organisasi tersebut, dengan begitu setiap peralatan\&perlengkapan yang dibutuhkan dapat memakai keuangan yang berasal dari penggalangan dana tersebut.

3 Melihat dari sisi kebutuhan mahasiswa Dalam hal ini Lembaga yang bekerja sama dengan perguruan tinggi harus diikut sertakan, karena dalam upaya ini dapat dilakukan dengan memberikan syarat apabila ingin mendapatkan beasiswa haruslah memiliki sertifikat keikutsertaan mahasiswa dalam berbagai organisasi, dengan begitu mahasiswa akan mencoba untuk bergabung dalam kegiatan organisasi.

C. Peran Organisasi dalam Pembentukan Karakter

Menurut (Kosasih, 2017) Organisasi yang baik adalah organisasi yang dapat menghasilkan orang-orang yang memiliki karakter sesuai norma yang ada. Ketika karakter tersebut sudah dimiliki oleh salah seorang mahasiswa, nantinya di dalam organisasi tersebut karakter tersebut dapat ditularkan kepada mahasiswa lainnya. Manusia adalah mahluk sosial yang tidak bisa menjalani kehidupan ini sendirian, tiap hari pasti ada saja hal-hal baru yang kita dapat temukan dari diri orang lain, dan disini penulis ingin menegaskan bahwa dalam berorganisasi lah karakter diri kita terbentuk. Berdasarkan dokumen Kementrian Pendidikan Nasional Direktorar Jenderal Pendidikan tinggi perihal nilai karakter mahasiswa, pelaksanaan tersebut di ormawa yaitu sebagai berikut 


\section{Kesimpulan}

Dalam rangka pelaksanaan supervisi maka harus mencakup semua komponen yang terkait dan mempengaruhi terhadap keberhasilan program supervisi. Supervisi merupakan kegiatan yang kompleks, oleh karena itu harus dilakukan oleh orang-orang profesional. Di dalam pengetian tersebut tergambar bahwa seorang supervisor harus orang yang memiliki jabatan resmi yang memiliki kewenangan atau otoritas dalam pengawasan

Sebagai salah satu sumber otoritas pelaksanaan supervisi oleh pengawas sekolah maka pengawas/supervisor memegang peranan yang sangat strategis dalam meningkatkan kualitas pembelajaran. Supervisi atau pembinaan tenaga pendidik oleh pengawas ini lebih menekankan pada pembinaan profesioanalisme yaitu pembinaan yang lebih ditujukan dalam upaya memperbaiki dan meningkatkan kemampuan profesionalisme guru

Pelaksanaan supervisi oleh pengawas sekolah mendasarkan prencanaan program yang telah disusun; meliputi tahap: persiapan, pelaksanaan, dan penilaian/ pelaporan.

Standar mutu pengawas yang telah ditetapkan oleh Direktorat Jenderal Peningkatan Mutu Pendidik dan Tenaga Kependidikan Direktorat Tenaga Kependidikan Departemen Pendidikan Nasional bahwa pengawas sekolah berfungsi sebagai supervisor baik supervisor akademik maupun supervisor manajerial.

\section{Bibliografi}

Almaidah, H. (2018). Pembentukan karakter mahasiswa melalui program pembentukan Kepribadian dan Kepemimpinan: Studi Kasus di Universitas Muhammadiyah Malang. Universitas Islam Negeri Maulana Malik Ibrahim.Google Scholar

Asy-Syarif, A. J., \& Sasongko, N. (2021). Pengaruh Kompensasi Bonus
Kepemilikan Manajerial Diversifikasi Perusahaan Ukuran Kap Dan Financial Stability Terhadap Manajemen Laba. Prosiding Seminar Nasional Kewirausahaan, 2(1). Google Scholar

Basri, B., \& Dwiningrum, N. R. (2020). Peran Ormawa dalam Membentuk Nilai-nilai Karakter di Dunia Industri (Studi Organisasi Kemahasiswaan di Politeknik Negeri Balikpapan). Al-Adabiya: Jurnal Kebudayaan Dan Keagamaan, 15(01), 139-158. Google Scholar

Danandjaja, J. (2014). Metode Penelitian Kepustakaan. Antropologi Indonesia. Google Scholar

Hemafitria, H., Rohani, R., \& Novianty, F. (2014). Pembinaan Karakter Mahasiswa melalui Organisasi Kemahasiswaan di STKIP-PGRI Pontianak. Edukasi: Jurnal Pendidikan, 12(2), 205-216. Google Scholar

Kosasih, K. (2017). Peranan Organisasi Kemahasiswaan Dalam Pengembangan Civic Skills Mahasiswa. Jurnal Pendidikan Ilmu Sosial, 25(2), 188-198. Google Scholar

Kusuma, S. (2018). Iklim Komunikasi Organisasi Dan Motivasi Kerja Pimpinan Dalam Mewujudkan Misi Perusahaan. Perspektif Komunikasi: Jurnal Ilmu Komunikasi Politik Dan Komunikasi Bisnis, 1(1). Google Scholar

Omeri, N. (2015). Pentingnya pendidikan karakter dalam dunia pendidikan. Manajer Pendidikan, 9(3). Google Scholar

Sofyan, H. (2013). Implementasi Pendidikan Karakter Melalui Kegiatan Kemahasiswaan. Tidak Diterbitkan. Google Scholar

岡戸順一，艾斌，巴山玉蓮，櫻井尚子, 藤原佳典，\& 星旦二. (2003). 主観的健康感を中心とした在宅高齢 者における健康関連指標に関寸る共 
分散構造分析

(特集

人々の健康を支援する方法).

総合都市研究， 81，19-30. Google

Scholar

\section{Copyright holder :}

Aprina Jovanka Sirait, Chontina Siahaan (2020).

First publication right :

Action Research Literate

This article is licensed under:
(c) (i) (2) 